Article

\title{
Investigation on Characteristics of Microwave Treatment of Organic Matter in Municipal Dewatered Sludge
}

\author{
Huafang Wang ${ }^{1,2}$, Jie Sun ${ }^{2}$, Yuzhe $\mathrm{Xu}^{2}$, Haowen Feng ${ }^{2}$, Ling Duan ${ }^{2}$ and $\mathrm{Xin} \mathrm{He}^{3, *(D)}$ \\ 1 State Key Laboratory of Geomechanics and Geotechnical Engineering, Institute of Rock and Soil Mechanics, \\ Chinese Academy of Sciences, Wuhan 430071, China; wanghfhust@163.com \\ 2 School of Mechanical Engineering and Automation, Wuhan Textile University, Wuhan 430200, China; \\ sunjie0529@163.com (J.S.); m18771927466@163.com (Y.X.); talestarry@163.com (H.F.); \\ lemon15972985973@163.com (L.D.) \\ 3 School of Applied Physics and Materials, Wuyi University, Jiangmen 529020, China \\ * Correspondence: hexinwyu@126.com
}

Received: 13 February 2019; Accepted: 16 March 2019; Published: 20 March 2019

check for updates

\begin{abstract}
This study aimed to utilize a microwave technology to degrade active organic matters of the municipal dewatered sludge in a high-temperature environment. The effects of extraction agent, nanomaterial assistants, and microwave-absorbing agents and activating agents on the degradation efficiency were investigated. Dimethyl carbonate was used as the extraction agent. Nanostructured titanium oxide $\left(\mathrm{TiO}_{2}\right)$ and zinc oxide $(\mathrm{ZnO})$ exhibited effective assistance in the process of microwave treatment. We also developed a kind of microwave-absorbing agent, which was the sludge-based biological carbon. The sodium sulfate $\left(\mathrm{Na}_{2} \mathrm{SO}_{4}\right)$, calcium hydroxide $\left(\mathrm{Ca}(\mathrm{OH})_{2}\right)$, and magnesium chloride $\left(\mathrm{MgCl}_{2}\right)$ were selected as activating agents to facilitate the organic matter discharging from the sludge. Through optimizing the experimental factors, it was confirmed that $0.1 \mathrm{wt} \% \mathrm{TiO}_{2}, 0.1 \mathrm{wt} \%$ $\mathrm{ZnO}, 2 \mathrm{wt} \%$ dimethyl carbonate, $10 \mathrm{wt} \%$ sludge-based biological carbon, $7.5 \mathrm{wt} \% \mathrm{Ca}(\mathrm{OH})_{2}, 0.5 \mathrm{wt} \%$ $\mathrm{MgCl}_{2}$, and $6 \mathrm{wt} \% \mathrm{Na}_{2} \mathrm{SO}_{4}$ were the most appropriate addition amounts in the municipal dewatered sludge to make the organic matter decrease from $42.17 \%$ to $22.45 \%$, and the moisture content reduce from $82.98 \%$ to $0.48 \%$ after the microwave treatment. By comparison, the organic matter degradation is almost zero, and the moisture content decreases to $8.69 \%$ without any additives. Moreover, the residual inert organic matter and sludge can be further solidified to lightweight construction materials by using liquid sodium silicate as the curing agent. The research provides a significant reference for the effective, fast, and low-cost treatment of the organic matter in the municipal sludge.
\end{abstract}

Keywords: municipal dewatered sludge; microwave; organic matter

\section{Introduction}

With the rapid development of construction in urban sewage treatment facilities, the rate of sewage concentrated disposal increased accordingly, resulting in a sharp increase in dewatered sludge quantity [1,2]. There are a large number of organic matters in the sludge, which usually exhibit different contents and compositions due to the variety of the source of sewage, treatment process, the living standard, and dietary habits of urban residents. Common sludge organic matter with high molecular weight and boiling point often contains twigs, sawdust, small cloth, bacteria, insect eggs, and other components [3]. However, the high content of organic matter in municipal dewatered sludge is easily corruptible if the disposition of organic matters is inappropriate, which not only causes environmental pollution, but also brings resource waste. Therefore, it is a great challenge to both manage municipal 
dewatered sludge by degrading the organic matters and explore an effective route to improve the degradation efficiency.

Usually, traditional sludge treatment strategies include concentration, dehydration and deweighting, dewatering, anaerobic and aerobic nitrification, pyrolysis, and drying [4-7]. As is well known, microwave irradiation is a new type of green energy, which contains both electric field and magnetic field. There are thermal effects and nonthermal effects under microwave irradiation, both of which conduct highly efficient treatments for the organic matter, heavy metal, and water in sludge $[8,9]$. When the nanostructured materials were irradiated by microwave, the dipole of organic matters surrounded by the nanostructured materials would generate turning-direction polarization. When the direction of the electric field with a high frequency is changed, the polarization direction of the dipole will accordingly alter. In the change process, a lot of heat is produced due to friction among the molecules, resulting in the temperature increase of the municipal dewatered sludge. Thus, the thermal effect of microwave treatment can promote the degradation of the organic matters [10-12].

At the same time, the nonthermal effect of microwave treatment is more significant. The microwave electric field increases the absorption efficiency and carrier separation of the nanostructured materials, and promotes water removal and formation of free groups. More importantly, the high-frequency electromagnetic waves of microwave radiation can penetrate the extraction medium and reach the vascular bundle and adenocyte system [13]. The temperature inside the cell rises quickly ascribes due to the absorption of microwave energy, leading to cell lysis. Consequently, the active components in the cells flow out freely, which can be captured and dissolved by the extraction medium at a low temperature. Therefore, microwave heating causes greater heating of materials compared with conventional heating methods. Furthermore, microwaves can penetrate inside materials, providing heat from inside to outside, which is advantageous to the volatilization of the water and organic matters. As a result, the thermal effect and nonthermal effect of the microwave treatment together lead to a fast organic matters extraction and sludge dewatering [14,15].

However, many organic matters with the characteristic of absorbing heating selectively cannot absorb the microwave energy, which generates poor degradation efficiency [16]. In order to improve the extraction of the organic matters from the sludge, we used the different additives into the sludge to enhance the interfacial interaction of the organic matters and sludge [17].

In this work, the microwave was utilized to treat the municipal dewatered sludge. The mixture of green extraction agent, a small amount of nanomaterials, and sludge-based microwave absorbent and activating agents was introduced into the sludge with the irradiation of microwave, resulting in a synergy effect to effectively improve the degradation of the organic matters.

\section{Materials and Methods}

The used sludge was taken from a sewage treatment plant of Wuhan City in Hubei. The sludge parameters are moisture content of $82.98 \mathrm{wt} \%$, natural density of $1.14 \mathrm{~kg} / \mathrm{m}^{3}, \mathrm{pH}$ of 7.07 , the content of organic matter is $42.17 \mathrm{wt} \%$, and the boiling point is $88^{\circ} \mathrm{C}$. The used microwave oven was self-designed and manufactured by Guangzhou Diwei Microwave Equipment Co., Ltd. (Guangzhou, China), and the output power of microwave ranged from 900 to $6300 \mathrm{~W}$.

We conducted the single factor experiment to confirm the optimized addition of extraction agent, nanomaterial assistants, microwave-absorbing agents, and activating agents. The typical experimental scheme: Firstly, municipal dehydrated sludge $\left(\mathrm{M}_{0}\right)$ was introduced into a polystyrene cup with the thermal decomposition temperature of over $300^{\circ} \mathrm{C}$, and then a certain amount of assistant nanomaterials $\left(\mathrm{TiO}_{2}\right.$ and $\mathrm{ZnO}$ nanoparticles), activating agents $\left(\mathrm{Na}_{2} \mathrm{SO}_{4}, \mathrm{Ca}(\mathrm{OH})_{2}\right.$ and $\left.\mathrm{MgCl}_{2}\right)$, and absorbing agents (sludge-based biological carbon) were added into the cup with constant stirring. The total weight of the mixture is $\mathrm{M}_{1}$. After the microwave treatment was conducted, the sludge was 
cooled to room temperature and weighted as $\mathrm{M}_{2}$. The quality reduction rate of the samples $\left(\psi_{1}\right)$ is evaluated by the following Equation (1).

$$
\psi_{1}=\left(\left(\mathrm{M}_{1}-\mathrm{M}_{2}\right) / \mathrm{M}_{0}\right) \times 100 \%
$$

The calculation method for the organic matter content: dry sludge $\left(\mathrm{M}_{2}\right)$ after microwave treatment was put into a ceramic crucible and the total weight is $\mathrm{M}_{3}$. The crucible was transferred into a muffle furnace for heating treatment at $600{ }^{\circ} \mathrm{C}$ for $6 \mathrm{~h}$, and the resultant weight is $\mathrm{M}_{4}$. The organic matter content is calculated by Equation (2).

$$
\psi_{2}=\left(\left(\mathrm{M}_{3}-\mathrm{M}_{4}\right) / \mathrm{M}_{2}\right) \times 100 \%
$$

Furthermore, we designed an orthogonal experiment to analyze the influence of activating agents, determining the most suitable addition amount.

\section{Results and Discussion}

Under microwave radiation, the sludge could be rapidly heated up, promoting the hydrolysis of carbohydrates into polysaccharides and monosaccharides with low molecular weights, and facilitating the hydrolysis of proteins into polypeptides, dipeptides, amino acids, and other substances that are further hydrolyzed into low molecular organic acids, ammonia, and carbon dioxide [12]. Meanwhile fat would be hydrolyzed into stearic acid, palmitic acid, and so on. Phosphorus and nitrogen in cells are also released due to the hydrolysis of nucleic acid. The mechanism illustration of microwave treatment for the municipal dewatered sludge is shown in Figure 1. The mixtures of farthing nanomaterials, green extraction agent, sludge-based microwave absorbent, curing binder, activator, and other low-cost materials are irradiated by microwave together, resulting in the degradation of the organic matters, and the dehydration and solidification of the residual materials.
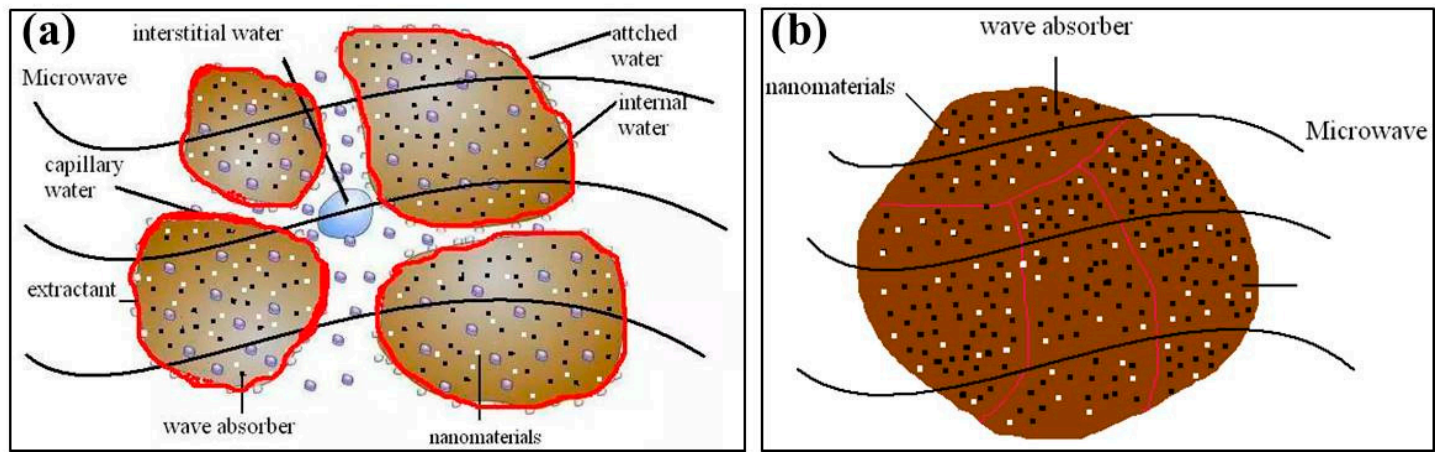

Figure 1. Illustration of sludge mixed with various additives (a) and municipal dewatered sludge after microwave treatment (b).

The above-mentioned hydrolysates could be extracted by suitable extractants [13]. Thus, the choice of extractants plays a significant role in determining the efficiency of the microwave treatment. As reported, dimethyl carbonate represents a new generation of nontoxic solvent, exhibiting the characteristics of safety, convenience, less pollution, and diverse dissolution to organic compounds [14, 15]. Thus, in this work, we investigated the effect of dimethyl carbonate as an extraction agent on the reduction rate of the organic matters under microwave irradiation.

The microwave treatment was conducted under the power of $6300 \mathrm{~W}$ for $2 \mathrm{~min}$ (an optimized condition). The generated temperature is approximately $93.4{ }^{\circ} \mathrm{C}$. The added mass ratios of the dimethyl carbonate are $0 \mathrm{wt} \%, 1 \mathrm{wt} \%, 2 \mathrm{wt} \%, 3 \mathrm{wt} \%$, and $4 \mathrm{wt} \%$, respectively. Figure 2 displays the variation tendencies of the sludge mass loss and the organic matter content as the content of the dimethyl carbonate increased. The plot shows that the quality loss of the sludge mixture is initially increased 
and then decreased, and the mass loss rate of the mixture reached a maximum of $79.90 \%$ with dimethyl carbonate content of $2 \mathrm{wt} \%$. Accordingly, the content of organic matter decreased from $42.17 \%$ in the initial stage to a minimum of $38.20 \%$. As calculated, the $2 \mathrm{wt} \%$ dimethyl carbonate extracts only $3.97 \%$ of the organic matter in the sludge under microwave radiation. There is still a lot of residual organic matter in the sludge. It is considered that the extraction efficiency of the organic matter is hardly improved by microwave radiation depending on dimethyl carbonate at a relatively low temperature of $93.4^{\circ} \mathrm{C}$, and the organic matters with high molecular weight were tightly attached to the sludge, so a higher energy is required to improve the extraction efficiency.

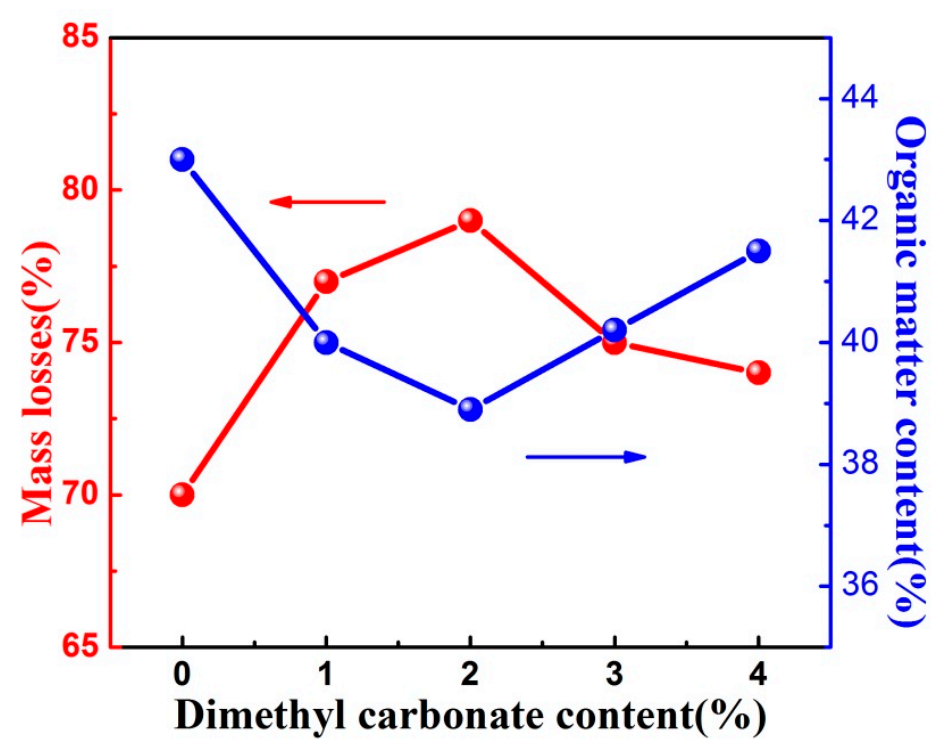

Figure 2. Mass loss of the sludge and content of the organic matters with respect to the content of the dimethyl carbonate during the process of the microwave treatment.

As is well known, nanomaterials have a large specific surface area and many defects, thus, they exhibit high surface adsorption and microwave absorption [15-19], which leads to the increase in temperature around the nanomaterials.

To investigate the effect of $\mathrm{ZnO}$ nanoparticles on the degradation efficiency of the organic matters, we mixed $0.2-1 \mathrm{wt} \% \mathrm{ZnO}$ pretreated powder and $2 \mathrm{wt} \%$ dimethyl carbonate with the municipal dewatered sludge under microwave treatment. Figure 3a presents the relationship of the mass loss and organic matter content with the added content of $\mathrm{ZnO}$. The plot reveals that the mass loss of the mixture initially increased as the $\mathrm{ZnO}$ content increased, and maintains a saturated value. Correspondingly, the organic matter content is greatly reduced when the added $\mathrm{ZnO}$ is increased to $0.1 \%$, and then displays a little increase. Thus, considering the nanomaterial cost, the amount of $\mathrm{ZnO}$ powder added in the sludge was selected as $0.1 \mathrm{wt} \%$. Through calculating the organic matter content, the result shows that it is decreased from $42.17 \%$ to $37.87 \%$ after microwave treatment, and the degradation rate of the organic matters in the sludge is $10.23 \%$, suggesting an effective treatment by using a small amount of $\mathrm{ZnO}$.

It was also found that the $\mathrm{TiO}_{2}$ nanomaterial is another kind of effective additive to assist in the degradation of organic matter. We conducted the microwave treatment using $0.1-0.5 \mathrm{wt} \% \mathrm{TiO}_{2}$ nanoparticles and $2 \mathrm{wt} \%$ dimethyl carbonate. Figure $3 \mathrm{~b}$ depicts the change of mass losses and organic matter content with the added content of $\mathrm{TiO}_{2}$, demonstrating a similar variation tendency with the case of $\mathrm{ZnO}$. Therefore, the added amount of $\mathrm{TiO}_{2}$ powder is set as $0.1 \mathrm{wt} \%$, and the content of organic matter is decreased from $42.17 \%$ to $24.68 \%$. The improvement in degradation efficiency of the organic matters by $\mathrm{ZnO}$ and $\mathrm{TiO}_{2}$ powders is mainly because the nanomaterials could be suspended on the surface of organic matters, and the friction between the nanomaterial and organic matter occur under 
the microwave with high frequency, leading to the requirement of a large amount of energy to improve the degradation efficiency of the organic matters.

Before microwave treatment, $\mathrm{ZnO}$ and $\mathrm{TiO}_{2}$ nanomaterials should undergo a surface modification process to reduce nanoparticle aggregation and improve the surface free energy of the nanomaterials. Thus, we put the nanomaterials into the microwave oven to facilitate short-term activation before mixing them with the sludge for the microwave treatment. When the microwave activation time is set below $10 \mathrm{~s}$, the degradation efficiency of the organic matters increased with the extension of activation time. However, if the time is set as 10-20 s, the degradation efficiency would gradually decrease. Thus, $10 \mathrm{~s}$ is an optimized pretreatment time, making the organic matter content decrease from $42.17 \%$ to $26.91 \%$.
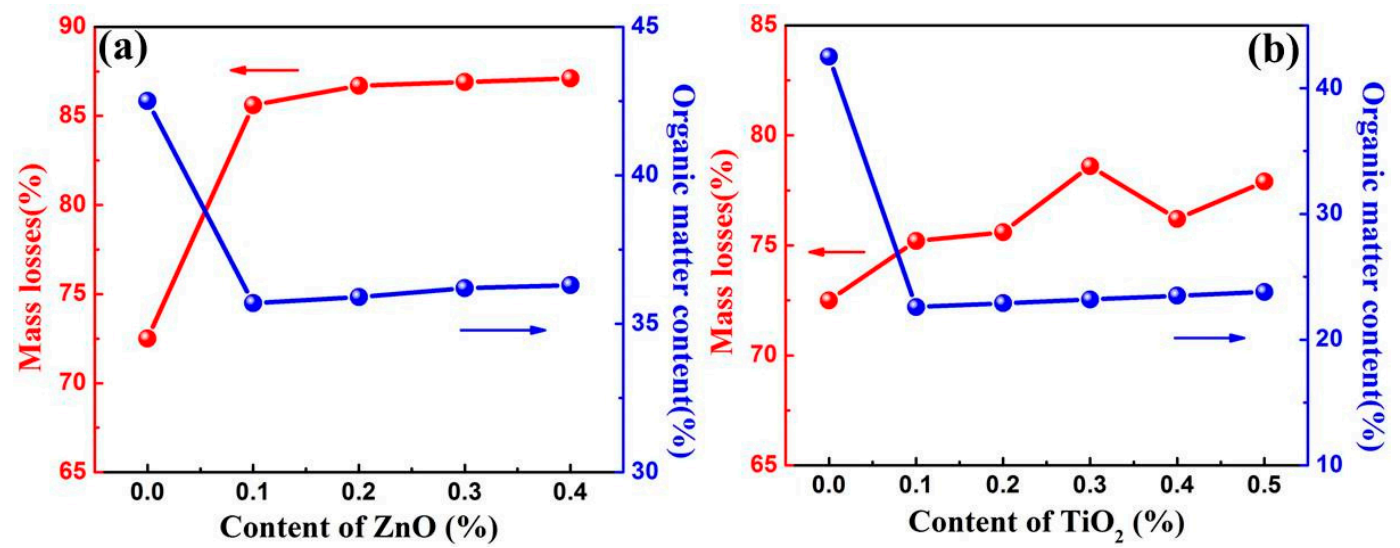

Figure 3. Relationship of mass losses and organic matter content with the content of $\mathrm{ZnO}(\mathbf{a})$ and $\mathrm{TiO}_{2}$ powder (b).

$\mathrm{ZnO}$ and $\mathrm{TiO}_{2}$ nanomaterials have been confirmed to effectively assist in degrading organic matter. Furthermore, to further improve the degradation efficiency, microwave-absorbing agents are also applied in the experiment. There have been many investigations that report their effects during the process of microwave treatment [20]. Sludge-activated carbon powder, due to its decontamination performance, was used as the microwave-absorbing agent in this work, which has been proven to exhibit high removal efficiency of some organic materials and heavy metals [21]. Thus, $2 \mathrm{wt} \%$ dimethyl carbonates, $0.1 \mathrm{wt} \% \mathrm{TiO}_{2}$, and $0.1 \mathrm{wt} \% \mathrm{ZnO}$ nanoparticles, as well as the sludge-activated carbon powder with content of $5 \mathrm{wt} \%, 10 \mathrm{wt} \%$, and $15 \mathrm{wt} \%$ were introduced into the sludge for the microwave treatment. The mixture without sludge-activated carbon powder is also carried out for comparison.

It should be mentioned that the temperature of the mixture is increased when the amount of the sludge-activated carbon enhanced. The highest temperature reached $212{ }^{\circ} \mathrm{C}$, when the content of sludge-activated carbon is $15 \mathrm{wt} \%$. The mass reduction rate of the mixture exceeded $10 \%$, and the content of the organic matters was remarkably decreased from $42.19 \%$ to $26.25 \%$, as displayed in Figure 4. The effective degradation of the organic matters is ascribed to the elevation of the temperature, and consequently resulted in the promotion of reactive activity. Furthermore, after microwave treatment, the sludge-based biological carbon changed to residual dry sludge consisting of carbonaceous materials, $\mathrm{ZnO}$ and $\mathrm{TiO}_{2}$ nanoparticles, and others. Thus, the dewatered sludge can be further used as raw material of the microwave absorber. 


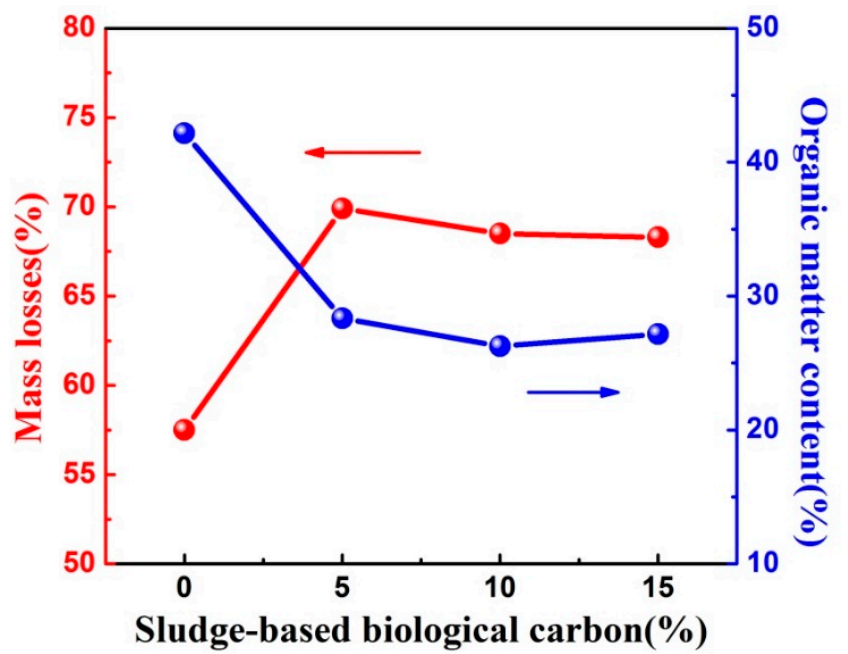

Figure 4. Effect of the sludge-based microwave absorber on mass losses and extraction of organic matter.

As reported, the organic matters could be effectively extracted with assistance of the cationic exchange resin [22]. In this work, we also introduced the inorganic salts into the reaction to promote the dissolution of protein, such as sodium sulfate, magnesium chloride, and calcium hydroxide, which were regarded as the microwave activators. They can not only adjust the acid-base balance of the sludge, but also improve the water removal [23]. Thus, we mixed sodium sulfate, magnesium chloride, and calcium hydroxide with the municipal dewatered sludge in the presence of $\mathrm{ZnO}$ and $\mathrm{TiO}_{2}$ nanoparticles. Figure $5 \mathrm{a}-\mathrm{c}$ presents the effects of added $\mathrm{MgCl}_{2}, \mathrm{Na}_{2} \mathrm{SO}_{4}$, and $\mathrm{Ca}(\mathrm{OH})_{2}$ with different mass ratios on the mass losses of sludge and organic matter content.
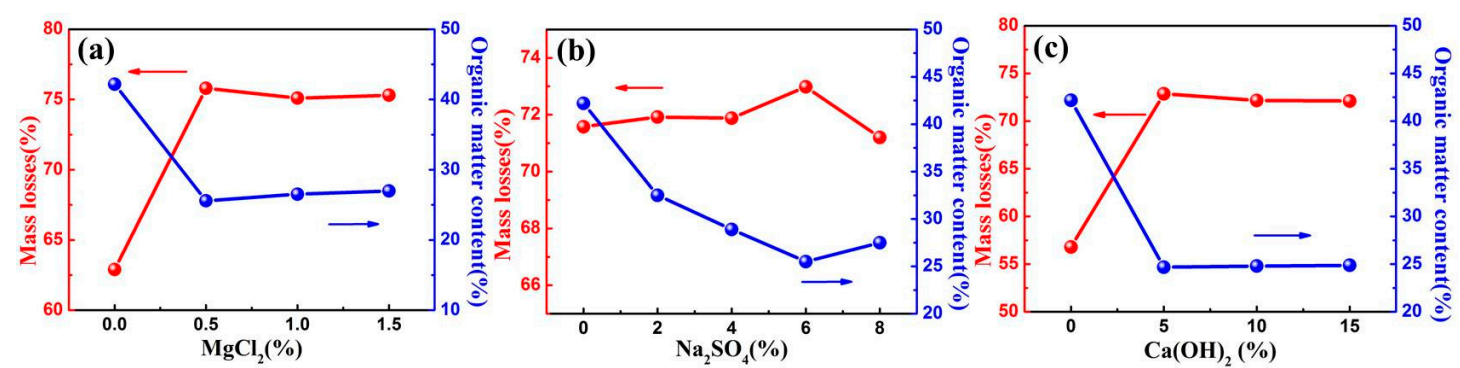

Figure 5. Effect of the $\mathrm{MgCl}_{2}(\mathbf{a}), \mathrm{Na}_{2} \mathrm{SO}_{4}(\mathbf{b})$, and $\mathrm{Ca}(\mathrm{OH})_{2}$ (c) added amounts on the mass losses and extraction of organic matter.

Figure 5a displays that the quality loss of the mixture is initially increased and then decreased as the content of $\mathrm{MgCl}_{2}$ gradually increased. The largest mass loss is achieved when the added amount of $\mathrm{MgCl}_{2}$ is $0.5 \mathrm{wt} \%$. The content of the organic matters decreased from $42.17 \%$ to $26.98 \%$ as the $\mathrm{MgCl}_{2}$ content increased from 0 to $1.5 \mathrm{wt} \%$. Figure $5 \mathrm{~b}$ shows that the mass loss rate of the mixture and reduction of the organic matters achieved the highest values when the content of $\mathrm{Na}_{2} \mathrm{SO}_{4}$ was $6 \mathrm{wt} \%$. Figure $5 \mathrm{c}$ shows that the sludge mass loss is firstly increased and then remains at a relative stable value as the content of $\mathrm{Ca}(\mathrm{OH})_{2}$ increased from 0 to $15 \mathrm{wt} \%$. The highest reduction rate of the sludge reached $72.86 \%$, while the content of the organic matters decreased from $42.17 \%$ to $24.68 \%$, with $\mathrm{Ca}(\mathrm{OH})_{2}$ content of $5 \mathrm{wt} \%$.

To further optimize the added amount of $\mathrm{MgCl}_{2}, \mathrm{Na}_{2} \mathrm{SO}_{4}$, and $\mathrm{Ca}(\mathrm{OH})_{2}$ in the process of the microwave treatment, we designed an orthogonal experiment to analyze the influence of each factor, and the orthogonal experiments determined the most suitable contents for $\mathrm{Ca}(\mathrm{OH})_{2}$ of $7.5 \mathrm{wt} \%, \mathrm{MgCl}_{2}$ of $0.5 \mathrm{wt} \%$, and $\mathrm{Na}_{2} \mathrm{SO}_{4}$ of $6 \mathrm{wt} \%$. The experimental results are listed in Table 1 . The effects of $\mathrm{MgCl}_{2}$, $\mathrm{Na}_{2} \mathrm{SO}_{4}$, and $\mathrm{Ca}(\mathrm{OH})_{2}$ on the mass loss of sludge and degradation of organic matters are crossed. It is necessary to elucidated the most suitable adding content of the microwave activators. In the orthogonal 
experiment, we mixed into the $20 \mathrm{~g}$ of sludge $\mathrm{TiO}_{2}$ nanoparticles of $0.02 \mathrm{~g}$, $\mathrm{ZnO}$ nanoparticles of $0.02 \mathrm{~g}$, dimethyl carbonate of $0.4 \mathrm{~g}$, and sludge-based biological carbon after this microwave treatment of $1 \mathrm{~g}$ together.

Table 1. Results of the orthogonal experiments.

\begin{tabular}{ccccccc}
\hline \multicolumn{2}{c}{ Orthogonality } & $\mathbf{M g C l}_{\mathbf{2}} / \%$ & $\mathbf{C a}(\mathbf{O H})_{2} / \%$ & $\mathbf{N a}_{\mathbf{2}} \mathbf{S O}_{\mathbf{4}} / \%$ & Quality Reduction Rate & Organic Matter Content \\
\hline 1 & $\mathrm{~A}_{1} \mathrm{~B}_{1} \mathrm{C}_{1}$ & 0.5 & 2.5 & 0.5 & $67.53 \%$ & $29.24 \%$ \\
2 & $\mathrm{~A}_{1} \mathrm{~B}_{2} \mathrm{C}_{2}$ & 0.5 & 5 & 1 & $67.90 \%$ & $28.79 \%$ \\
3 & $\mathrm{~A}_{1} \mathrm{~B}_{3} \mathrm{C}_{3}$ & 0.5 & 7.5 & 1.5 & $69.88 \%$ & $29.18 \%$ \\
4 & $\mathrm{~A}_{2} \mathrm{~B}_{1} \mathrm{C}_{2}$ & 1 & 2.5 & 1 & $68.16 \%$ & $30.99 \%$ \\
5 & $\mathrm{~A}_{2} \mathrm{~B}_{2} \mathrm{C}_{3}$ & 1 & 5 & 1.5 & $68.38 \%$ & $30.62 \%$ \\
6 & $\mathrm{~A}_{2} \mathrm{~B}_{3} \mathrm{C}_{1}$ & 1 & 7.5 & 0.5 & $67.01 \%$ & $30.54 \%$ \\
7 & $\mathrm{~A}_{3} \mathrm{~B}_{1} \mathrm{C}_{3}$ & 1.5 & 2.5 & 1.5 & $70.01 \%$ & $30.06 \%$ \\
8 & $\mathrm{~A}_{3} \mathrm{~B}_{2} \mathrm{C}_{1}$ & 1.5 & 5 & 0.5 & $70.89 \%$ & $30.13 \%$ \\
9 & $\mathrm{~A}_{3} \mathrm{~B}_{3} \mathrm{C}_{2}$ & 1.5 & 7.5 & 1 & $71.14 \%$ & $26.91 \%$ \\
\hline
\end{tabular}

Finally, in order to further solidify the residual organic matters, we introduced liquid water glass into the mixture to conduct a curing process using the waste heat. In the experiment, $0.1 \mathrm{wt} \% \mathrm{ZnO}$ nanoparticles, $0.1 \mathrm{wt} \% \mathrm{TiO}_{2}$ nanoparticles, $2 \mathrm{wt} \%$ dimethyl carbonate, $10 \mathrm{wt} \%$ sludge-based biological carbon, $0.5 \mathrm{wt} \% \mathrm{MgCl}_{2}, 7.5 \mathrm{wt} \% \mathrm{Ca}(\mathrm{OH})_{2}, 6 \mathrm{wt} \% \mathrm{Na}_{2} \mathrm{SO}_{4}$, and liquid water glass, with added amount ratios of $0 \mathrm{wt} \%, 1 \mathrm{wt} \%, 2 \mathrm{wt} \%, 3 \mathrm{wt} \%, 4 \mathrm{wt} \%$, and $5 \mathrm{wt} \%$, were introduced into $20 \mathrm{~g}$ of sludge. Figure 6 reveals that the mass loss rate of the mixture and content of the organic matters maintain relative stable values when the content of liquid water glass was elevated, indicating that the liquid water glass cannot play a significant role in promoting the degradation, but it can solidify the residual organic matters and sodium silicate in the sludge mixture to produce lightweight construction materials using one-step microwave irradiation. The compressive strength is remarkably enhanced over $2 \mathrm{MPa}$. When the content of the liquid water glass was $5 \mathrm{wt} \%$, the mass loss rate of the mixture reached $72.01 \%$, and the content of organic matter was reduced from $42.17 \%$ to $22.45 \%$. Only $\sim 46.76 \%$ of the inert organic matter was stable in the sludge.

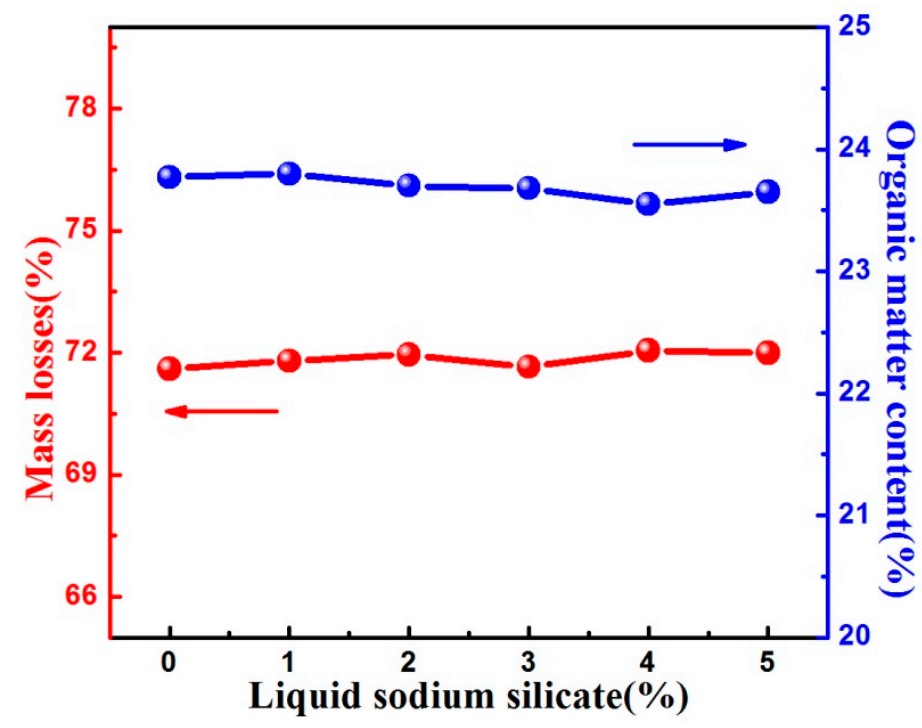

Figure 6. Effects of liquid water glass curing binder on microwave treatment.

In this work, we always put cost into the consideration. The total addition of the microwave solvent and nanomaterial assistants is $2.2 \mathrm{wt} \%$. The usage of dry municipal dewatered sludge as the microwave-absorbing agent can further reduce the cost. The activating agents are industrial by-products. By calculation, if one ton of municipal dewatered sludge is treated the cost of power 
consumption is 56 RMB. The price of added microwave solvent, nanomaterial assistants, and liquid sodium silicate is $168 \mathrm{RMB}$. After microwave treatment, 0.6 ton of lightweight construction materials is produced, which has a value of $300 \mathrm{RMB}$. Thus, we can obtain a profit of $76 \mathrm{RMB}$ per ton.

\section{Conclusions}

In this study, we investigated the effects of the extraction agent, nanomaterial assistant, microwave-absorbing agent, and activating agent on the degradation efficiency of the organic matters in municipal dewatered sludge, which were conducted under the microwave treatment with a power of $6300 \mathrm{~W}$ for $2 \mathrm{~min}$. A high-temperature environment for sludge treatment was created in these cases. The results showed that the optimized factors of the additives are as follows; the content of dimethyl carbonate as the extraction agent is $2 \%$ and the added amounts of $\mathrm{ZnO}$ and $\mathrm{TiO}_{2}$ nanoparticles, as nanomaterial assistants, are $0.1 \%$ and $0.1 \%$, respectively. The content of sludge-activated carbon as microwave-absorbing agent is $10 \%$. The contents of $\mathrm{MgCl}_{2}, \mathrm{Na}_{2} \mathrm{SO}_{4}$, and $\mathrm{Ca}(\mathrm{OH})_{2}$ as activating agents are $0.5 \mathrm{wt} \%, 6 \mathrm{wt} \%$, and $7.5 \mathrm{wt} \%$, respectively. The liquid water glass was introduced into the reaction to conduct a curing process, making the solidification of the residual organic matters and improving the compressive strength of the sludge simultaneously. This work developed a fast, facile, low-cost, and harmless technology for the treatment of municipal sewage sludge. During the treatment, we took the balance between the treatment cost and the ecological benefit of the environment into consideration, and realized the high value utilization of municipal sewage sludge.

Author Contributions: Conceptualization, H.W.; Investigation, J.S., Y.X., H.F., and L.D.; Writing-Original Draft Preparation, H.W.; Writing-Review and Editing, X.H.; Supervision, X.H.; Funding Acquisition, H.W.

Funding: This work was supported by the Educational Commission of Hubei Province of China (D20171604); the Hubei Provincial Natural Science Foundation of China (2018CFB673); the Wuhan Morning Light Plan of Youth Science and Technology (2017050304010323); the National Natural Science Foundation of China (51405348); China Postdoctoral Science Foundation (2014M552124); the Wuhan Textile University Foundation (153038); and the Key Laboratory of Optoelectronic Materials and Applications in Guangdong Higher Education (2017KSYS011).

Conflicts of Interest: The authors declare no conflict of interest.

\section{References}

1. Müller, J.A. Prospects and problems of sludge pre-treatment. Water Sci. Technol. 2001, 44, 121-128. [CrossRef] [PubMed]

2. Shimizu, T.; Toyono, M.; Ohsawa, $\mathrm{H}$. Emissions of $\mathrm{NO}_{x}$ and $\mathrm{N}_{2} \mathrm{O}$ during co-combustion of dried sewage sludge with coal in a circulating fluidized bed combustor. Fuel 2007, 86, 957-964. [CrossRef]

3. Narita, H.; Isshiki, I.; Funamizu, N.; Takakuwa, T.; Nakagawa, H.; Nishimura, S.I. Organic matter released from activated sludge bacteria cells during their decay process. Environ. Technol. 2005, 26, 433-440. [CrossRef] [PubMed]

4. Hallas, J.F.; Mackowiak, C.L.; Wilkie, A.C.; Harris, W.G. Struvite phosphorus recovery from aerobically digested municipal wastewater. Sustainability 2019, 11, 376. [CrossRef]

5. Jindaroma, C.; Meeyoob, V.; Kitiyanana, B.; Rirksomboona, T.; Rangsunvigita, P. Surface characterization and dye adsorptive capacities of char obtained from pyrolysis/gasification of sewage sludge. Chem. Eng. J. 2007, 133, 239-246. [CrossRef]

6. Ischia, M.; Perazzolli, C.; Dal Maschio, R.; Campostrini, R. Pyrolysis study of sewage sludge by TG-MS and TG-GC-MS coupled analyses. J. Therm. Anal. Calorim. 2007, 87, 567-574. [CrossRef]

7. Scott, S.A.; Dennis, J.S.; Davidson, J.F.; Hayhurst, A.N. Thermogravimetric measurements of the kinetics of pyrolysis of dried sewage sludge. Fuel 2006, 85, 1248-1253. [CrossRef]

8. Sujeeta, K.; Jeeban, P.; Sea, C.O. Thermal pre-treatment of sewage sludge in a lab-scale fluidized bed for enhancing its solid fuel properties. Appl. Sci. 2018, 8, 183.

9. Martínez, E.J.; Gil, M.V.; Rosas, J.G.; Moreno, R.; Mateos, R.; Morán, A.; Gómez, X. Application of thermal analysis for evaluating the digestion of microwave pre-treated sewage sludge. J. Therm. Anal. Calorim. 2017, 127, 1209-1219. [CrossRef] 
10. Menezes, R.R.; Souto, P.M.; Kiminami, R.H.G.A. Microwave hybrid fast sintering of porcelain bodies. J. Mater. Process. Technol. 2007, 190, 223-229. [CrossRef]

11. Yu, Y.; Chan, W.I.; Lo, I.W.; Liao, P.H.; Lo, K.V. Sewage sludge treatment by a continuous microwave enhanced advanced oxidation process. Can. J. Civ. Eng. 2010, 37, 796-804. [CrossRef]

12. Frølund, B.; Palmgren, R.; Keiding, K.; Nielsen, P.H. Extraction of extracellular polymers from activated sludge using a cation exchange resin. Water Res. 1996, 30, 1749-1758. [CrossRef]

13. Yoshikawa, N.; Kawahira, K.; Saito, Y.; Todoroki, H.; Taniguchi, S. Estimation of microwave penetration distance and complex permittivity of graphite by measurement of permittivity and direct current conductivity of graphite powder mixtures. J. Appl. Phys. 2015, 117, 084105. [CrossRef]

14. Lin, Q.H.; Chen, G.Y.; Liu, Y.K. Scale-up of microwave heating process for the production of bio-oil from sewage sludge. J. Anal. Appl. Pyrolysis 2012, 94, 114-119. [CrossRef]

15. Zhao, M.; Johnson, M.; He, W.Z.; Li, G.M.; Zhao, C.; Yu, L.L.; Huang, J.W.; Zhu, H.C. Ultrarapid multimode microwave synthesis of nano/submicron $\beta$-SiC. Materials 2018, 11, 17. [CrossRef]

16. Pimentel, A.; Samouco, A.; Nunes, D.; Araujo, A.; Martins, R.; Fortunato, E. Ultra-fast microwave synthesis of $\mathrm{ZnO}$ nanorods on cellulose substrates for UV sensor applications. Materials 2017, 10, 1308. [CrossRef]

17. Ahmad, R.; Kim, J.K.; Kim, J.H.; Kim, J. Nanostructured ceramic photocatalytic membrane modified with a polymer template for textile wastewater treatment. Appl. Sci. 2017, 7, 1284. [CrossRef]

18. Cai, A.J.; Guo, A.Y.; Ma, Z.C. Immobilization of $\mathrm{TiO}_{2}$ nanoparticles on chlorella pyrenoidosa cells for enhanced visible-light-driven photocatalysis. Materials 2017, 10, 541. [CrossRef]

19. Kim, J.H.; Lee, J.H.; Kim, J.Y.; Kim, S.S. Synthesis of aligned $\mathrm{TiO}_{2}$ nanofibers using electrospinning. Appl. Sci. 2018, 8, 309.

20. Ara, E.; Sartaj, M.; Kennedy, K. Effect of microwave pre-treatment of thickened waste activated sludge on biogas production from co-digestion of organic fraction of municipal solid waste, thickened waste activated sludge and municipal sludge. Waste Manag. Res. 2014, 32, 1200-1209. [CrossRef]

21. Kim, M.; Hyun, S.; Sung, J.S. Adsorptive attenuation of ferrocyanide from seepage water in landfill clay liners. Environ. Earth Sci. 2013, 68, 2007-2014. [CrossRef]

22. Menéndez, J.A.; Domínguez, A.; Inguanzo, M.; Pis, J.J. Microwave-induced drying, pyrolysis and gasification (MWDPG) of sewage sludge: Vitrification of the solid residue. J. Anal. Appl. Pyrolysis 2005, 74, 406-412. [CrossRef]

23. Liu, H.; Zhang, Q.; Hu, H.Y.; Xiao, R.X.; Li, A.J.; Qiao, Y.; Yao, H.; Naruse, I. Dual role of conditioner CaO in product distributions and sulfur transformation during sewage sludge pyrolysis. Fuel 2014, 134, 514-520. [CrossRef]

(C) 2019 by the authors. Licensee MDPI, Basel, Switzerland. This article is an open access article distributed under the terms and conditions of the Creative Commons Attribution (CC BY) license (http://creativecommons.org/licenses/by/4.0/). 